\title{
Basal Ganglia Output Controls Active Avoidance Behavior
}

\author{
Sebastian Hormigo, German Vega-Flores, and $₫$ Manuel A. Castro-Alamancos \\ Department of Neurobiology and Anatomy, Drexel University College of Medicine, Philadelphia, Pennsylvania 19129
}

Engrained avoidance behavior is highly adaptive when it keeps away harmful events and can be highly maladaptive when individuals elude harmless situations in anxiety disorders, but the neural circuits that mediate avoidance are poorly understood. Using DREADDs and optogenetics in mice, we show that the output of the basal ganglia through the substantia nigra pars reticulata (SNr) controls active avoidance. SNr excitation blocks avoidance to a conditioned sensory stimulus while preserving the ability to escape the harmful event. Conversely, SNr inhibition facilitates avoidance to the conditioned stimulus and suffices to drive avoidance without any conditioned sensory stimulus. The results highlight a midbrain circuit that gates avoidance responses, which can be targeted to ameliorate maladaptive avoidance in psychiatric disorders.

Key words: approach; avoidance; escape; midbrain; substantia nigra; superior colliculus

\section{Significance Statement}

In many circumstances, subjects respond to fearful situations with avoidance. This is a useful coping strategy in situations in which there is impending danger. However, avoidance responses can also be maladaptive, as in anxiety disorders such as phobias (e.g., avoiding air transportation) and social anxiety (e.g., avoiding social situations). Despite the obvious clinical relevance, little is known about the neural circuits that mediate active avoidance. Using chemogenetics and optogenetics, we show that the output of the basal ganglia fully controls active avoidance behavior.

\section{Introduction}

In active avoidance conditioning (Mowrer, 1960; Bolles, 1970; Mineka, 1979; Bouton, 2007; Krypotos et al., 2015), animals learn to avoid an aversive event by producing an appropriate behavioral response (avoidance) during an interval signaled by the presentation of a conditioned stimulus (CS); the aversive outcome is contingent on the behavior of the subject. This contrasts with Pavlovian fear conditioning, a procedure in which the aversive outcome is not contingent on the behavior of the subject. In Pavlovian fear conditioning, the association between a neutral stimulus and an aversive event leads to the elicitation of fear responses in the form of immobility, potentiated startle, changes in heart rate, etc., which were not initially evoked by the CS. Many studies have identified the amygdala as an essential part of the neural circuitry involved in Pavlovian fear conditioning (LeDoux, 2000; Davis and Whalen, 2001; Maren, 2001; Ciocchi et al., 2010; Haubensak et al., 2010; Pape and Pare, 2010; Tye and De-

\footnotetext{
Received June 8, 2016; revised July 11, 2016; accepted July 28, 2016.

Author contributions: M.A.C.-A. designed research;S.H., G.V.-F., and M.A.C.-A. performed research;S.H., G.V.-F., and M.A.C.-A. analyzed data; M.A.C.-A. wrote the paper.

This work was supported by the National Institutes of Health (M.A.C.-A.) We thank the National Institute on Drug

Abuse drug supply program for providing clozapine-N-oxide and Z. Gui, V. Rovira, and D. Fox for assistance.

The authors declare no competing financial interests.

Correspondence should be addressed to Dr. Manuel A. Castro-Alamancos, Department of Neurobiology

and Anatomy, Drexel University College of Medicine, 2900 Queen Lane, Philadelphia, PA 19129.

DOI:10.1523/JNEUROSCI.1842-16.2016

Copyright $\odot 2016$ the authors $\quad 0270-6474 / 16 / 3610274-11 \$ 15.00 / 0$
}

isseroth, 2012), The amygdala, and its connections with the striatum, appear to have an important role in early stages (acquisition) of active avoidance learning (Killcross et al., 1997; Amorapanth et al., 2000; LeDoux and Gorman, 2001; Delgado et al., 2009; Darvas et al., 2011; Zweifel et al., 2011), but it may not be critically involved afterward during the performance (expression) of the learned behavior (Roozendaal et al., 1993; Poremba and Gabriel, 1999). In fact, animals well trained in active avoidance do not appear to be fearful of the CS (Kamin et al., 1963), and CS termination functions as a safety signal (Bolles and Grossen, 1970; Bolles, 1970). During CS onset, well trained animals show cortical electrophysiological patterns that are consistent with a quiescent (nonaroused) deactivated state (Castro-Alamancos, 2004a, 2004b). Therefore, avoidance appears to occur out of habit, motivated by an internal representation of fear and/or by the safety signaled by CS termination (Rescorla and Solomon, 1967; Bolles, 1970; Seligman, 1972; Mineka, 1979).

Performance of active avoidance in well trained animals likely involves the interplay between at least three related neural systems: the structures associated with the sensory modality (auditory, somatosensory, or visual) that processes the CS, the structures that drive the conditioned locomotor response, and an intermediate circuit that gates avoidance to the CS. The output structure of the basal ganglia, the substantia nigra pars reticulata $(\mathrm{SNr})$, is an excellent candidate for this gating role. The basal ganglia control movement and are involved in action selection (Mink, 1996; Redgrave et al., 1999; Gurney et al., 2001) and rein- 
forcement learning (Schultz, 1998; Barnes et al., 2005; Redgrave and Gurney, 2006; Berridge, 2007; Graybiel, 2008; Cohen et al., 2012; Oleson et al., 2012). The striatum regulates $\mathrm{SNr}$ cell activity via two pathways: a direct inhibitory pathway and an indirect excitatory pathway through the globus pallidus external and subthalamic nucleus (Albin et al., 1989; Smith et al., 1998; Hikida et al., 2010; Kravitz et al., 2010; Kravitz and Kreitzer, 2012; Tai et al., 2012; Cui et al., 2013; Freeze et al., 2013; Tecuapetla et al., 2014). Cells in the SNr are GABAergic and tonically active (Chevalier and Deniau, 1990) and project to the superior colliculus, pedunculo-tegmental nucleus (PPT; aka pedunculo-pontine tegmental nucleus), and certain thalamic nuclei (Di Chiara et al., 1979; Gulcebi et al., 2012) and leave collaterals within the substantia nigra pars compacta (SNc) (Tepper et al., 1995; Richards et al., 1997). SNr cells pause their tonic firing during orienting movements (Hikosaka and Wurtz, 1983; Wurtz and Hikosaka, 1986; Schmidt et al., 2013). Because the superior colliculus is under inhibitory control from the $\mathrm{SNr}$, the ramping up of neural firing observed in the superior colliculus during active avoidance (Cohen and Castro-Alamancos, 2010b) implies that SNr activity is suppressed during avoidance.

To test the role of the output of the basal ganglia on the performance of active avoidance behavior, we used chemogenetics and optogenetics to control the activity of SNr cells in a vesicular GABA transporter-IRES-Cre mouse strain (Vgat-Cre; Jax016962) (Vong et al., 2011). With these mice, we can express hM3Dq-DREADD, hM4Di-DREADD (Urban and Roth, 2015), channelrhodopsin-2 (ChR2) (Boyden et al., 2005), or a variant of archaerhodopsin (ArchT) (Han et al., 2011) in SNr cells. Neurons expressing hM3Dq are excited, whereas neurons expressing hM4Di are inhibited, after intraperitoneal injections of clozapine- $N$-oxide (CNO). Neurons expressing ChR2 are excited by blue light, whereas neurons expressing ArchT are inhibited by green light. We found that exciting $\mathrm{SNr}$ cells blocks active avoidance driven by the CS, but spares the ability to escape the aversive stimulus. Conversely, inhibiting $\mathrm{SNr}$ cells facilitates avoidance driven by the CS and suffices to drive avoidance in the absence of the CS.

\section{Materials and Methods}

Animals. All procedures were reviewed and approved by the Animal Care Committee of Drexel University and were conducted in adult $(>8$ weeks) male mice. In chemogenetics experiments, two groups of mice were used: SNr-hM3Dq and SNr-hM4Di. SNr-hM3Dq mice were obtained by injecting $0.3 \mu \mathrm{l}$ of AAV5-hSyn-DIO-hM3D(Gq)-mCherry [University of North Carolina (UNC) Vector Core, Chapel Hill] into the $\mathrm{SNr}$ bilaterally (to express the excitatory DREADD). SNr-hM4Di mice were obtained by injecting $0.3 \mu \mathrm{l}$ of AAV5-hSyn-DIO-hM4D(Gi)mCherry (UNC Vector Core) into the SNr bilaterally (to express the inhibitory DREADD). The coordinates for $\mathrm{SNr}$ injections were (bregmalambda plane): $3.0-3.3 \mathrm{~mm}$ posterior from bregma, $1.4 \mathrm{~mm}$ lateral from the midline, and $4.1 \mathrm{~mm}$ ventral from bregma. Figure $1 A$ shows an example of mCherry expression in the midbrain of a SNr-hM3Dq mice. mCherry expression filled the $\mathrm{SNr}$ bilaterally. In some cases, additional expression was observed dorsal to the $\mathrm{SNr}$, representing nigrofugal fibers and/or spread of the adeno-associated virus (AAV) to adjacent structures (see Fig. $1 A$ ). Expression outside of $\mathrm{SNr}$ was minimal and variable between injections and did not correlate with the effects of $\mathrm{CNO}$ on active avoidance.

In optogenetics experiments, two groups of mice were used: $\mathrm{SNrChR} 2$ and RosaArch. SNrChR2 mice were obtained by injecting Vgat-Cre mice with $0.3 \mu \mathrm{l}$ of AAV5.EF1a.DIO. hChR2 (H134R)-eYFP.WPRE.hGH [University of Pennsylvania (UPenn) Vector Core, Philadelphia] into the SNr bilaterally. RosaArch mice were obtained by crossing Vgat-Cre and ROSA-ArchT (Jax021188) homozygotes to express ArchT in most GABAergic cells. Active avoidance testing procedures commenced 2-3 weeks after AAV injections. SNrArch mice were used for electrophysiology experiments (see Fig. 5) and were obtained by injecting Vgat-Cre mice with $0.3 \mu \mathrm{l}$ of AAV5.CBA.Flex.Arch-GFP.WPRE.SV40 (UPenn Vector Core) into the SNr bilaterally.

In vivo recordings to test DREADDs and optogenetics. Mice used previously for active avoidance were used for these experiments. After induction of anesthesia with urethane ( $1.5 \mathrm{~g} / \mathrm{kg}$, i.p.; DREADDs) or ketamine-xylazine (100-5 mg/kg; regularly supplemented; Optogenetics), animals were placed in a stereotaxic frame. Skin incisions and frame contacts with the skin were injected with lidocaine (2\%). Craniotomies and incisions of the dura were made over the target structures (bilateral $\mathrm{SNr}$ ) as necessary. Body temperature was automatically maintained constant with a heating pad at $37^{\circ} \mathrm{C}$. The level of anesthesia was monitored with limb withdrawal reflexes and was kept constant at about stage III/3 (i.e., absence of pinch withdrawal reflex, absence of whisker movements) using supplemental doses.

For DREADDs experiments, two tungsten electrodes (1-5 M $\Omega$ ) were moved independently into the $\mathrm{SNr}$ on each side of the brain to record single units or multiunits. SNr units were easily identified based on their high tonic firing rate $(>10 \mathrm{~Hz})$ and narrow spike width, which contrasts with the wide spike width and slow firing, sometimes in bursts, of SNc cells (Guyenet and Aghajanian, 1978; Tepper et al., 1995). After a stable baseline of at least $1 \mathrm{~h}, \mathrm{CNO}$ was injected $(20 \mathrm{mg} / \mathrm{kg}$, i.p.) and recording continued for an additional $3 \mathrm{~h}$. This dose was chosen because it produced a significant electrophysiological effect (see Results).

For optogenetics experiments, two tungsten electrodes (1-5 M $\Omega$ ) were moved independently into the intermediate layers of the superior colliculus and barrel cortex on the same side of the brain to record single units or multiunits (Cohen et al., 2008). An optic fiber was lowered into the $\mathrm{SNr}$ on the same side of the brain at the above-mentioned coordinates. In addition, a set of contralateral whiskers were mechanically deflected. Mechanical whisker deflections were performed by placing multiple whiskers $(\sim 6)$ in several glass pipettes $(1 / 0.5 \mathrm{~mm}$ outer/inner diameter) that were glued to the membrane of miniature speakers. Application of a $1 \mathrm{~ms}$ square current pulse to the speakers deflected the micropipette and the whiskers inside. The resulting whisker deflection was a very low amplitude $\left(\sim 2^{\circ}\right)$ and very high velocity $\left(\sim 1000^{\circ} / \mathrm{s}\right) \mathrm{stim}-$ ulus. Each of the whisker stimulators was driven by counter/timer boards controlled with LabVIEW software (National Instruments).

In vitro (slice) recordings to test optogenetics. The SNrChR2 and RosaArch mice were used for these experiments. For slice preparation, mice were deeply anesthetized with an overdose of ketamine. Upon losing all responsiveness to a strong tail pinch, the animal was decapitated and the brain was rapidly extracted. Slices ( $400 \mu \mathrm{m}$ thick) were cut in the coronal plane using a vibratome at the level of SNr. Slices were transferred to an interface chamber, where they were bathed constantly $(1-1.5 \mathrm{ml} / \mathrm{min})$ with artificial CSF (ACSF) at $32.5^{\circ} \mathrm{C}$. The ACSF contained the following (in $\mathrm{mm}$ ): $126 \mathrm{NaCl}, 3.5 \mathrm{KCl}, 1.25 \mathrm{NaH}_{2} \mathrm{Po}_{4}, 26 \mathrm{NaHCO}_{3}, 10$ dextrose, 2 $\mathrm{MgSO}_{4} 7 \mathrm{H}_{2} \mathrm{O}$, and $2 \mathrm{CaCl}_{2} 2 \mathrm{H}_{2} \mathrm{O}$. Blind whole-cell recordings were obtained from the $\mathrm{SNr}$ using patch electrodes of 4-12 $\mathrm{M} \Omega$ impedance. The electrodes were filled with internal solution containing the following (in mM): $135 \mathrm{~K}$-gluconate, $4 \mathrm{KCl}, 2 \mathrm{NaCl}, 0.2 \mathrm{EGTA}, 10$ Trisphosphocreatine, 0.3 Tris-GTP, 10 HEPES, and 4 MgATP (290 mOsm). Each slice was imaged using a compound fluorescent microscope to reveal the parts of the $\mathrm{SNr}$ that contained eYFP-labeled fibers, which allowed verification of the correct placement of AAV injections in the SNr. In RosaArch mice, the $\mathrm{SNr}$ was extremely bright (see Fig. $2 C$; by far the brightest structure in the midbrain; Vong et al., 2011). At the end of each recording, the slice was imaged again (light and fluorescence) to record the location of the recording electrodes. In addition, in most cases the internal solution contained neurobiotin $(0.2 \%)$ to label the recorded cells (see Fig. 2C).

In slice experiments, a $200-\mu \mathrm{m}$-core-diameter multimode optic fiber coupled to LEDs was used to apply pulses of blue $(470 \mathrm{~nm})$ or green (532 $\mathrm{nm}$ ) light in the $\mathrm{SNr}$ (around the recording site). The light intensity was computer controlled by adjusting the output range of the light source. In addition, the intensity (irradiance) of the light beam exiting the optic fiber was measured by flashing a photodiode power sensor placed in the location of the slice. The light intensity range was $0-40.4 \mathrm{~mW} / \mathrm{mm}^{2}$. 
A

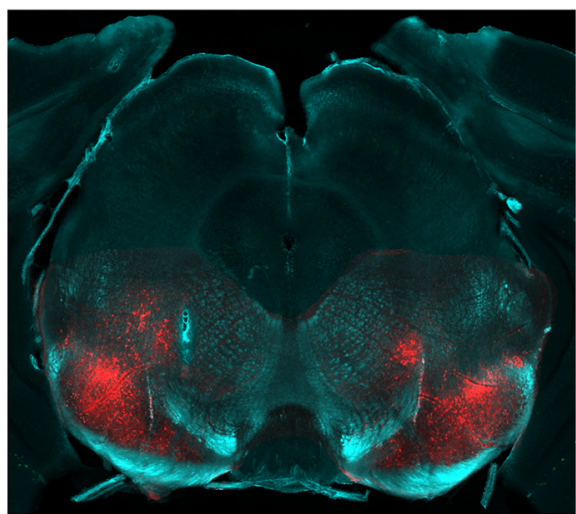

c
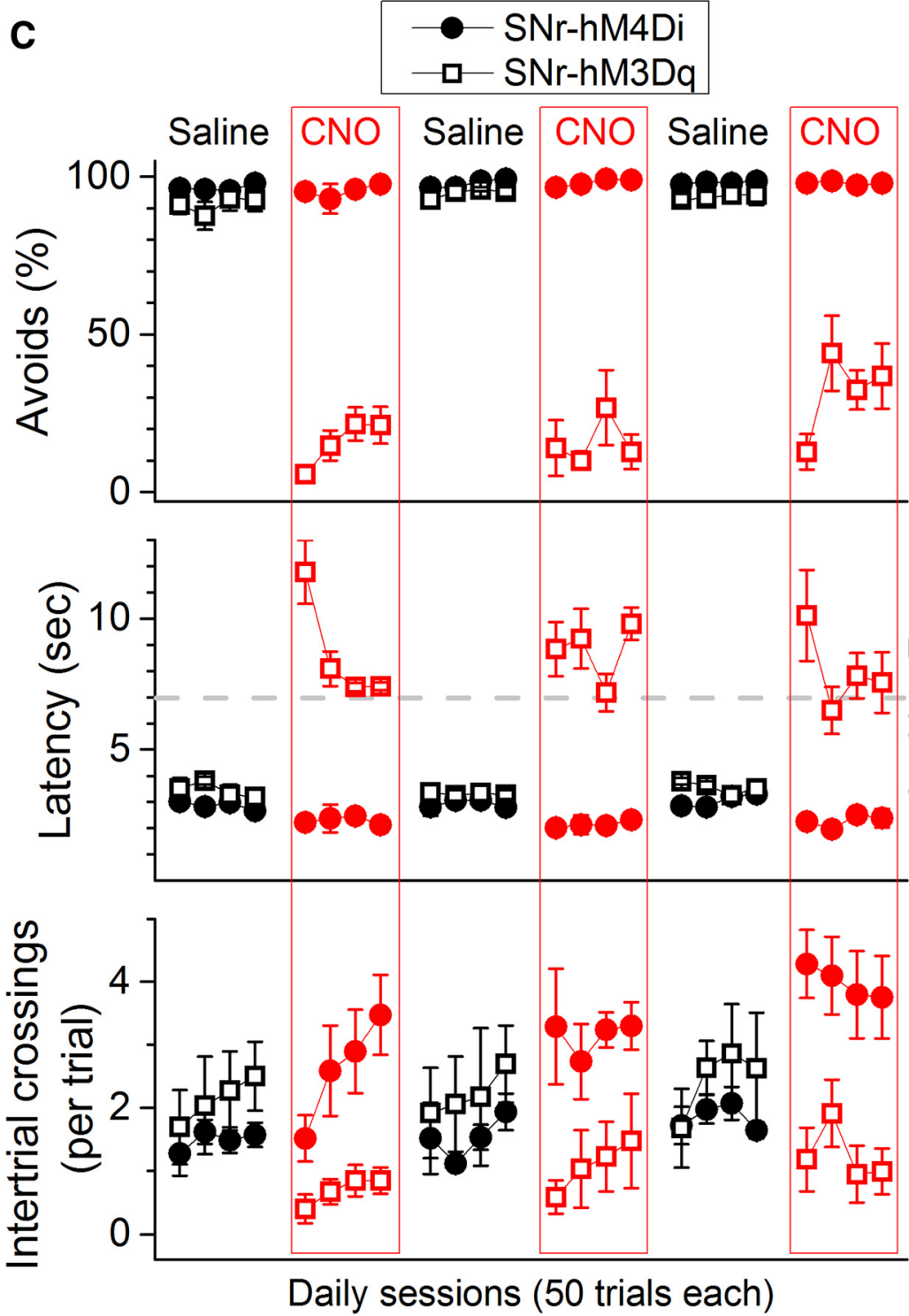

B

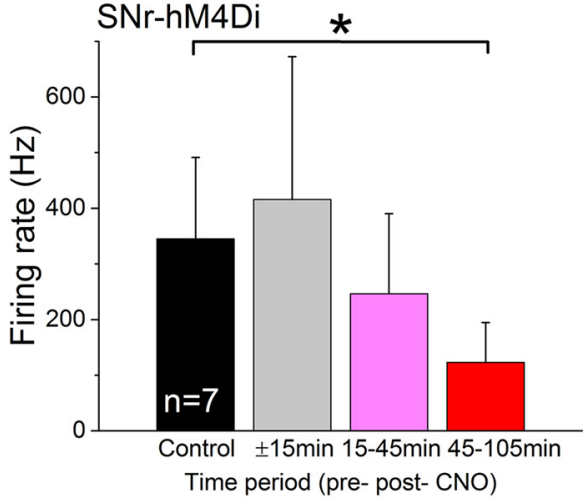


A

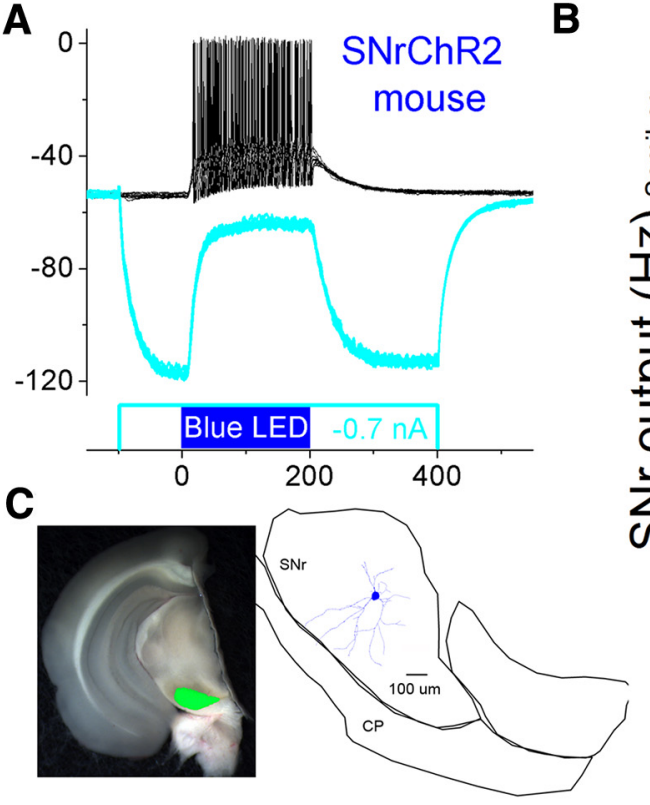

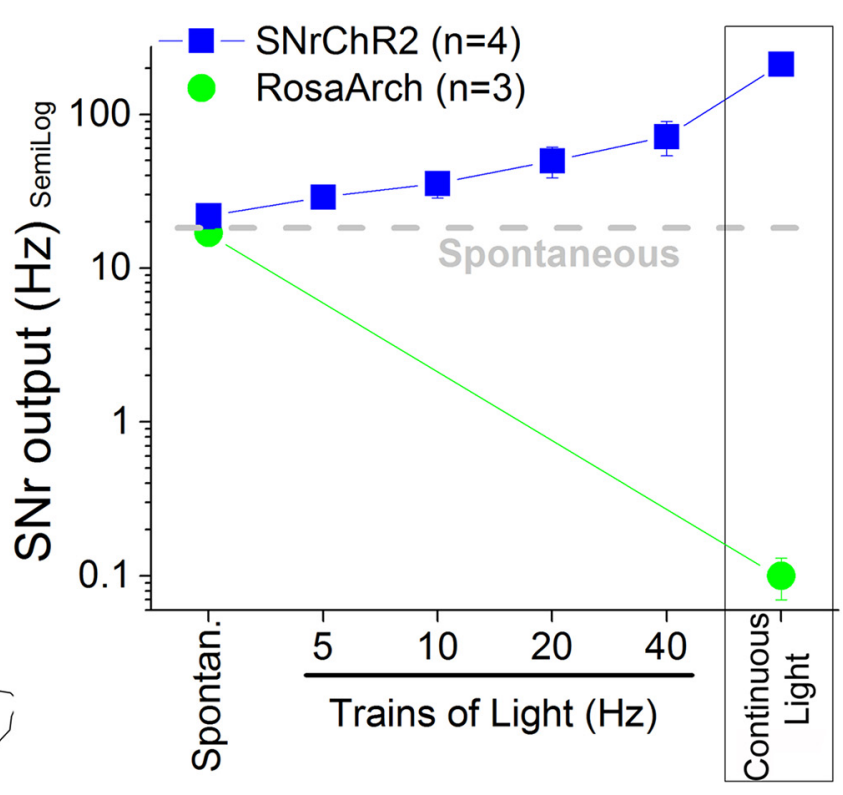

Figure 2. Optogenetic control of SNr cells. A, Continuous pulses depolarize a SNr cell in a SNrChR2 slice. A hyperpolarizing pulse before the blue light pulse hyperpolarizes the membrane potential and reveals the ChR2-induced depolarization. $\boldsymbol{B}$, Population data showing the effect of trains of pulses at different frequencies and continuous pulses on the spontaneous firing of $S \mathrm{Nr}$ cells in the two groups of mice used for optogenetics. Trains of blue light pulses increase the firing rate of SNr cells in SNrChR2 slices in a frequency-dependent manner. Constant pulses of blue light increase the firing of SNr cells in SNrChR2 slices. Constant pulses of green light block the firing of SNr cells in RosaArch slices. C, Photomicrographs taken in the slice chamber blending the eYFP fluorescence (green) and the visible light in a coronal slice used for whole-cell recordings from a RosaArch mouse. Note the robust fluorescence in SNr reflecting opsin expression. A recorded and reconstructed neurobiotinfilled SNr cell is shown.

Single pulses or trains of blue light stimuli were applied at a minimum of $4 \mathrm{~s}$ apart between each other.

After each slice experiment, the slices were fixed in $4 \%$ paraformaldehyde with $1 \%$ glutaraldehyde and later cryoprotected with sucrose $(30 \%)$ and resectioned on a cryostat $(80 \mu \mathrm{m})$. To further determine the extent of ChR2 expression, sections were mounted, coverslipped with DAPI mounting medium, and photographed using a fluorescent microscope. Fluorescent sections that contain neurobiotin-filled cells were incubated in $0.2 \%$ Triton X-100 and $2 \%$ goat serum, followed by Dylight594streptavidin. Sections were then mounted, coverslipped with DAPI mounting medium, and photographed using a fluorescent microscope. The eYFP from the ChR2 or Arch expression appears slightly green, the neurobiotin-filled cell appears slightly red, and DAPI appears slightly blue. Cells were reconstructed using Neurolucida (Microbrightfield).

Active avoidance. Mice were trained in the active avoidance task using procedures similar to those described previously for rats (Cohen and Castro-Alamancos, 2007, 2010b). Animals were placed in a standard shuttle box controlled using MedPC software (MED Associates) consisting of 2 compartments separated by a partition extending minimally ( 2 $\mathrm{mm}$ ) up from the grid floor (with side walls forming a door way) that the animal had to traverse to shuttle between compartments. A single training trial consisted of a $7 \mathrm{~s}$ avoidance interval, followed by a $10 \mathrm{~s}$ escape interval. During the avoidance interval, a CS ( $8 \mathrm{kHz}, 90 \mathrm{~dB}$ tone) was presented for the duration of the interval or until the animal produced a conditioned (avoidance or avoid) response by moving to the adjacent compartment, whichever occurred first. If the animal avoided, the CS was terminated and no escape interval was presented. However, if the animal did not avoid, then during the escape interval, an unconditioned stimulus (US) consisting of a $90 \mathrm{~dB}$ white noise tone plus a mild scrambled electric foot shock $(0.3 \mathrm{~mA})$ was delivered through the grid floor of the occupied half of the shuttle box. The US motivated the animal to move readily to the adjacent compartment (escape), at which point the US terminated, ending the trial. During the intertrial interval, the animal awaited the next trial and was free to cross between compartments at will. These spontaneous responses are called intertrial crossings. The duration of the intertrial interval in the avoidance task was randomly distributed within a range of $25-45 \mathrm{~s}$. The recorded variables representing task per- formance are the percentage of avoidances and the latency from the CS onset. All animals in the study always escaped the US.

Optogenetics during active avoidance. Optogenetics during active avoidance was accomplished by using 2 optic fibers plugged into a dual optic cannula $(200 \mu \mathrm{m}$ in diameter, $3 \mathrm{~mm}$ apart) implanted bilaterally in the $\mathrm{SNr}$ at the above-mentioned posterior and ventral coordinates (see Fig. 3B) $\sim 5-7 \mathrm{~d}$ before resuming performance in the task. The dual optic cannula was implanted using ketamine-xylazine (100 mg/kg - $5 \mathrm{mg} / \mathrm{kg}$; regularly supplemented) or isoflurane anesthesia $(\sim 1 \%)$ and held in place with a combination of screws and dental cement. Animals received carprofen immediately after surgery.

The optic fibers were connected to a dual light swivel (Doric Lenses) coupled to a blue laser $(450 \mathrm{~nm} ; 80 \mathrm{~mW})$ or a green laser $(532 \mathrm{~nm} ; 100$ $\mathrm{mW})$. On the first session after optic fiber implantation, different light intensities were tested and the intensity selected was the one that produced no obvious overt motor reactions such as head movements or turning biases, as described below. In daily sessions, three different types of active avoidance trials were presented randomly. Auditory CS (ACS) trials were control trials in which the ACS was presented alone. In ACS + light CS (LCS) trials, the optogenetic stimulation was presented simultaneously with the ACS and persisted during presentation of the US if the animal did not avoid. In the LCS trials, the optogenetic stimulation was presented alone (replacing the ACS) to determine whether it could drive avoidances in the absence of the ACS.

In SNrChR2 mice, the blue light (measured at each of the optic fibers; not counting loss from the implanted optic cannula) was adjusted to the minimal level that on the first session consistently blocked avoidances during continuous stimulation in ACS + LCS trials (range of power: 1-3 $\mathrm{mW}$; corresponding irradiance: $32-95 \mathrm{~mW} / \mathrm{mm}^{2}$ ). For trains of pulses in SNrChR2 mice, the same light intensity as for continuous pulses was used and the duration of the pulses in the train was adjusted to the minimum duration that would block avoidances during trains of stimulation at 66 $\mathrm{Hz}$ in ACS + LCS trials (SNrChR2 mice). This duration $(\sim 1 \mathrm{~ms})$ was used for all frequencies tested. The logic of this procedure is that, in $\mathrm{SNrChR} 2$ mice, it ensures that a sufficient pulse duration to activate $\mathrm{SNr}$ cells. In RosaArch mice, the green light was used at a range of $25-30 \mathrm{~mW}$ $\left(796-955 \mathrm{~mW} / \mathrm{mm}^{2}\right)$ and was adjusted to produce no visible overt mo- 
tor reactions. During active avoidance, a black aluminum cap completely covered the head implant where the dual optic cannula and the optic fibers connected, blocking any exiting light. After the last active avoidance session, the effects of different intensities of light stimulation applied unilaterally on movement biases in an open field were tested (i.e., the tendency of an animal to move in a certain direction during active exploration; see Fig. 4).

Statistical analysis. If the data were considered normally distributed according to the Shapiro-Wilk normality test, parametric statistics were used. A two-way mixed-design ANOVA followed by comparisons with Tukey's test (for more than two levels) were used to test for a main effect (CNO or light). In the mixed-design ANOVA, the repeatedmeasures factor was the light (with as many levels as conditions) or CNO (two levels) effect and the other factor was the daily sessions. If the data were considered not normally distributed, nonparametric multiple-comparison statistics consisting of the Wilcoxon signed-rank tests were used. When performing multiplecomparisons, $p$-values were adjusted using a Bonferroni correction by correcting the $p$-value by the number of comparisons made. Independent comparisons between different groups of mice were not performed because all conclusions are based on within group comparisons.

\section{Results}

Effect of modulating SNr activity with DREADDs on active avoidance

We first tested whether modulating the activity of SNr cells using DREADDs would have any impact on active avoidance behavior. Vgat-Cre mice were infused bilaterally $(0.3 \mu \mathrm{l})$ with either AAV5-hSyn-DIOhM4D(Gi)-mCherry ( $n=6$; SNr-hM4Di) or AAV5-hSyn-DIO-hM3D(Gq)-mCherry $(n=5$; SNr-hM3Dq) into the SNr (Fig. $1 A$ ). To determine the effective period of DREADDs activation after CNO injection, SNr-hM4Di mice (infused with the AAV 5 weeks earlier) were anesthetized with urethane and subjected to stereotaxic surgery. Single electrodes were lowered into each $\mathrm{SNr}$ to record from single units and multiunits. We found that activation of hM4Di with $\mathrm{CNO}(20 \mathrm{mg} / \mathrm{kg}$, i.p.) significantly suppressed the spontaneous firing of SNr cells $(n=7$; Wilcoxon, $p=0.01$; Fig. $1 B)$ measured during a $1 \mathrm{~h}$ period starting $45 \mathrm{~min}$ after CNO injection.

Mice were initially trained in 5 sessions ( 50 trials per daily session) to shuttle between compartments in a 2-way shuttle box during the presentation of an auditory CS (ACS; $90 \mathrm{~dB}, 8 \mathrm{kHz}$ for $7 \mathrm{~s}$ ) to avoid an aversive event (US) consisting of a combination of white noise $(90 \mathrm{~dB})$ plus a mild foot shock $(0.2-0.3 \mathrm{~mA})$. The US was presented until the animal escaped or for a maximum of $10 \mathrm{~s}$. In successive daily sessions, animals were subjected to either saline or $\mathrm{CNO}$ (20 mg/kg, i.p.) injections $45 \mathrm{~min}$ before active avoidance performance. A series of four consecutive saline sessions was followed by a series of four consecutive CNO sessions and this sequence was repeated three times. Activation of hM3Dq
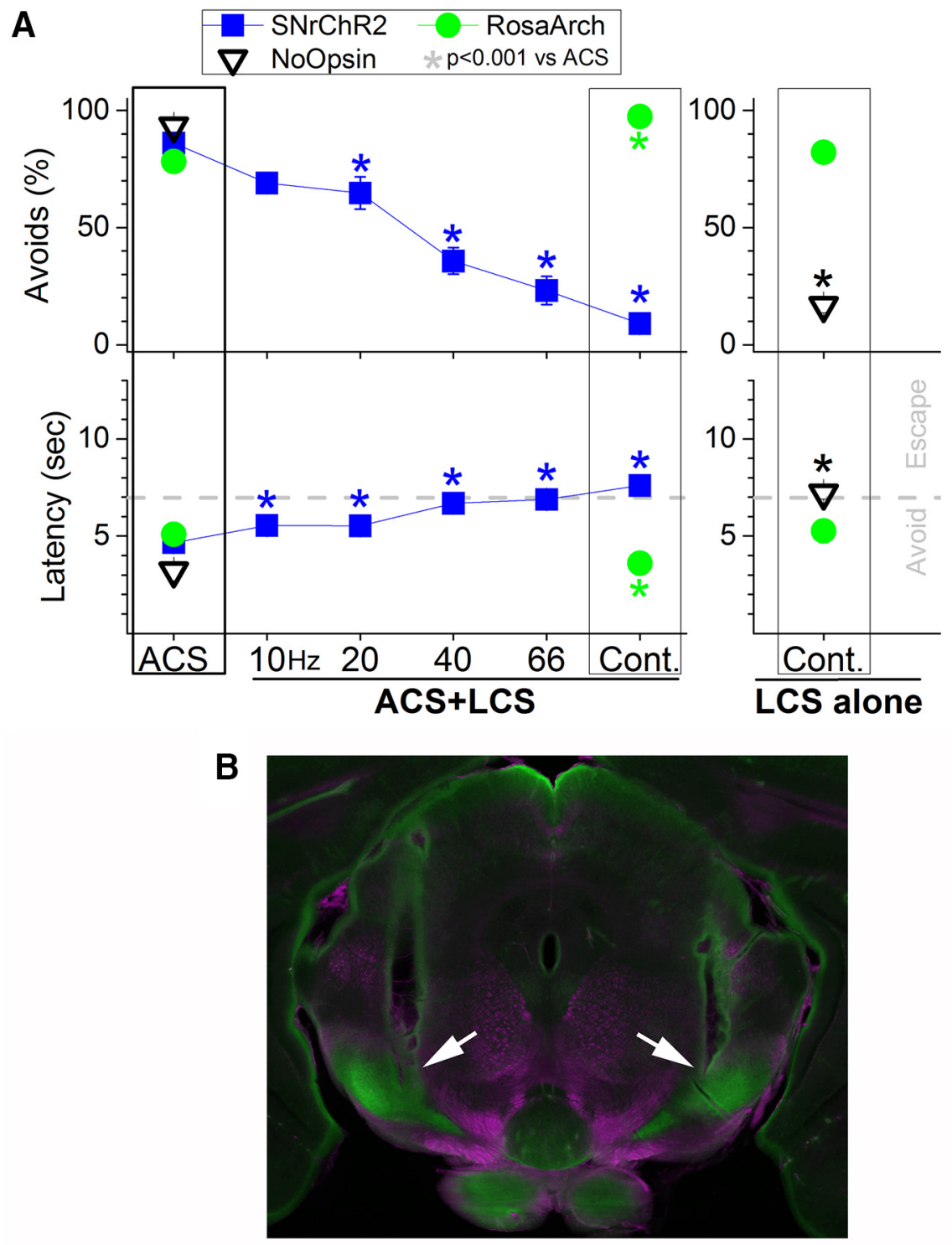

Figure 3. Effects of optogenetics in SNr on active avoidance. $\boldsymbol{A}$, Trains of blue light in the SNr of SNrChR2 mice $(n=3)$ produced a gradual frequency-dependent (SNr firing-dependent as shown in Fig. $2 B$ ) blocking of active avoidance during presentation of the SNr cells. Continuous pulses of green light in RosaArch mice $(n=3)$ facilitate avoidance during presentation of the ACS (ACS + LCS trials) and drive avoidance in the absence of the ACS (LCS alone trials). Mice expressing no opsins and receiving continuous pulses showing the tracks of a dual cannula implanted bilaterally in the SNr of a RosaArch mouse (arrows). Image blends a dark-field image of the section with the green channel of the fluorescent image.

with CNO ( $n=60 \mathrm{CNO}$ sessions in $n=5$ mice; Fig. $1 C$, open squares) significantly impaired the ability of the animals to avoid compared with saline in the same mice ( $n=60$ saline sessions). The impairment was specific to avoidance because the animals readily escaped the US (Fig. $1 C$, right panels). CNO significantly reduced the percentage of avoids (two-way mixed design ANOVA, $F_{(1,48)}=$ $1051.5 ; p<0.0001)$, increased the latency from ACS onset $\left(F_{(1,48)}=\right.$ $326.1 ; p<0.0001)$, reflecting the fact that avoids became escapes, and decreased the number of spontaneous intertrial crossings $\left(F_{(1,48)}=28.7 ; p<0.0001\right)$.

In contrast, activation of hM4Di with $\mathrm{CNO}(n=72 \mathrm{CNO}$ sessions in $n=6$ mice; Fig. $1 C$, closed circles), which suppresses the spontaneous firing of SNr cells (Fig. $1 B$ ), significantly facilitated the ability of the animals to avoid compared with saline in 
the same mice ( $n=72$ saline sessions). CNO could not improve the percentage of avoidances because these were already $\sim 100 \%$ in saline sessions $\left(F_{(1,60)}=0.25, p=0.61\right)$, but CNO significantly decreased the latency from ACS onset $\left(F_{(1,60)}=68.9, p<0.0001\right)$. This effect was accompanied by a significant increase in the number of spontaneous intertrial crossings $\left(F_{(1,60)}=105.04, p<\right.$ $0.0001)$. The DREADDs results indicate that excitation of $\mathrm{SNr}$ output blocks active avoidance selectively without interfering with the ability to escape the US. Conversely, inhibition of $\mathrm{SNr}$ output makes well trained animals avoid faster.

\section{Effect of modulating $\mathrm{SNr}$ with optogenetics on active avoidance}

Because DREADDS produces an overall time-unselective modulation of $\mathrm{SNr}$ activity, to further test the idea that $\mathrm{SNr}$ cells control active avoidance, we used optogenetics to control SNr activity selectively during presentation of the ACS and US in two groups of mice. SNrChR2 mice were Vgat-Cre mice that received bilateral AAV5.EF1a.DIO.hChR2 (H134R)-eYFP.WPRE.hGH injections $(0.3 \mu \mathrm{l})$ in the $\mathrm{SNr}$ to express ChR2 in SNr cells. RosaArch mice were obtained by crossing Vgat-Cre and ROSA-ArchT (Jax021188) homozygotes to express ArchT in most GABAergic cells. We first characterized the effects of light pulses on SNr cells in adult slices of brain tissue from our two groups of mice. Whole-cell recordings were used to determine the effects of continuous pulses ( $500 \mathrm{~ms}$ ) and trains of pulses ( 8 pulses at $5,10,20$, and $40 \mathrm{~Hz} ; 1 \mathrm{~ms}$ duration per pulse) on the firing of SNr cells (Fig. $2 A, B$ ). In SNr cells of SNrChR2 mice (Fig. 2A), trains of blue light produced an increase in firing rate as a function of increases in train frequency that peaked with continuous pulses of blue light (Fig. 2B). In addition, continuous pulses of green light in RosaArch mice silences SNr cells (Fig. 2B).

To test the effect of exciting or inhibiting $\mathrm{SNr}$ firing on active avoidance, bilateral fiber optic cannulas were implanted in the $\mathrm{SNr}$ of SNrChR2 $(n=3)$ and RosaArch $(n=3)$ mice. Animals underwent daily sessions in which three types of active avoidance trials were presented randomly. ACS trials were control trials in which the ACS was presented alone. In ACS + LCS trials, the optogenetic stimulation was presented simultaneously with the ACS and persisted during presentation of the US if the animal did not avoid. In LCS-alone trials, the optogenetic stimulation was presented alone (replacing the ACS) to determine whether it could drive avoidances in the absence of the ACS. Optogenetic stimulation consisted of continuous light pulses (blue or green) or trains of light pulses (blue) at different frequencies (10, 20, 40, and $66 \mathrm{~Hz}$ ) applied bilaterally to the SNr. The intensity of light pulses and the duration of the pulses in the trains $(\sim 1 \mathrm{~ms})$ were selected for each animal on the first session (see Materials and Methods). Intertrial crossings were minimal and not significantly affected by any of the optogenetic stimuli in any of the groups of mice studied and are not shown.

We found that increasing the firing of SNr cells in SNrChR2 mice by increasing the frequency of blue light trains produced a gradual deterioration of active avoidance that was complete during continuous pulses of blue light (Fig. $3 \mathrm{~A}$, blue squares; $n=20$ sessions per stimulus type in 3 mice). All sessions included ACS trials, continuous ACS + LCS trials, and trains of ACS + LCS trials (Movie 1). The results show that increasing the frequency of blue light produced a concomitant reduction in the percentage of avoidances and increased the latency from ACS onset in ACS + LCS compared with ACS trials within the same sessions. Impairment of avoidance was maximal at the highest train frequency ( 66 $\mathrm{Hz} ; n=20$ sessions in 3 mice; Tukey's test, $p<0.0001)$ and

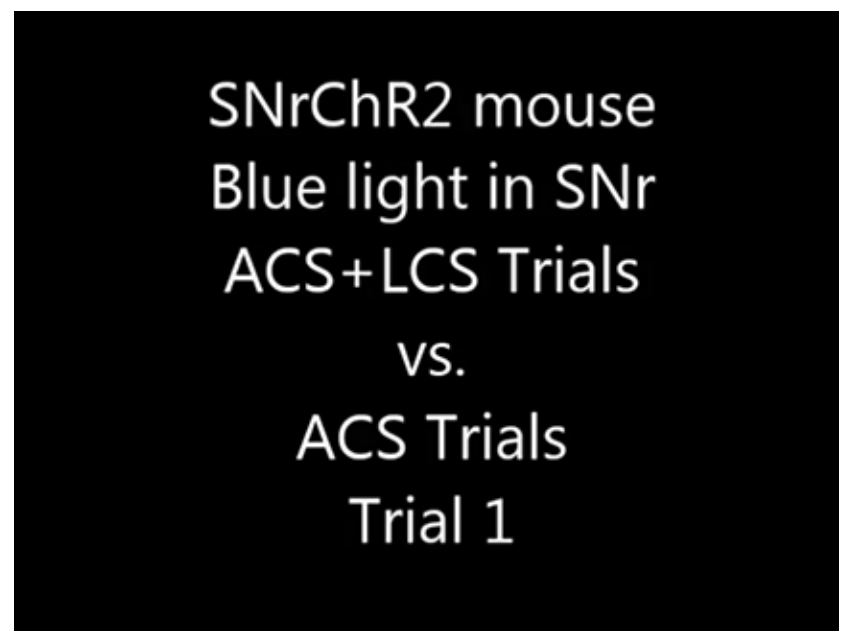

Movie 1. Sixteen randomly presented ACS and ACS + LCS (continuous pulses of blue light or $1 \mathrm{~ms}$ trains at 20 or $40 \mathrm{~Hz}$ ) trials in a SNrChR2 mouse followed by 5 LCS-only trials (continuous pulses of green light) in a RosaArch mouse (ACS trials are not shown for this mouse).
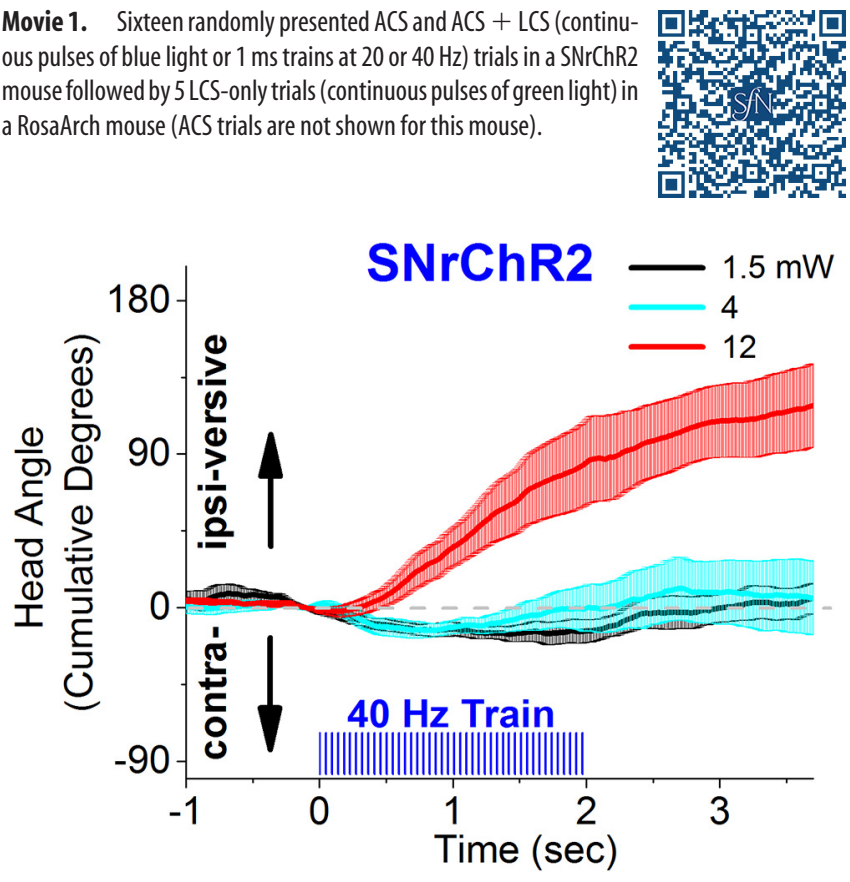

Figure 4. Effect of different light intensities (power) on spontaneous movement bias in an open field. The figure shows head angle video tracking ( 100 frames per second) from a SNrChR2 mouse subjected to unilateral stimuli consisting of a $2 \mathrm{~s}$ train $(40 \mathrm{~Hz}, 1 \mathrm{~ms})$ of blue light at different light intensities, including the one used during active avoidance (black traces). A consistent turning bias occurs at the higher light power, indicating that the intensities we used during avoidance are at the lower end for SNr modulation.

during continuous blue light stimulation $(n=20$ sessions in 3 mice; Tukey's test, $p<0.0001)$. Importantly, despite the abolishment of avoidance, the animals had no impairment in escaping the US (note the fast escape latencies of $\sim 0.5 \mathrm{~s}$ from US onset), indicating that increasing $\mathrm{SNr}$ firing impairs avoiding, not escaping, selectively.

Conversely, inhibition of SNr cell firing rate in RosaArch mice with continuous pulses of green light facilitated active avoidance during presentation of the ACS (Fig. 3A, green circles; Movie 1). The percentage of avoidances increased significantly ( $n=16$ sessions in 3 mice; Tukey, $p<0.0001$ ) and the latency from ACS onset decreased significantly (Tukey's test, $p<0.0001$ ) in ACS + LCS compared with ACS trials within the same sessions. Moreover, inhibition of $\mathrm{SNr}$ cell firing rate in RosaArch mice was sufficient to drive avoidance without the ACS. Therefore, the 
A

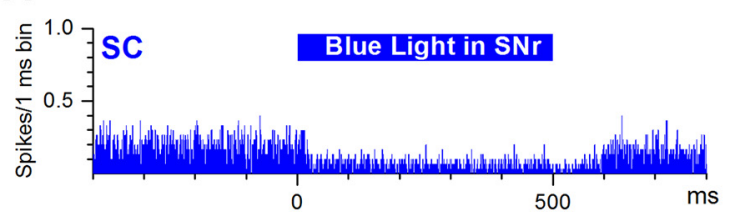

SC

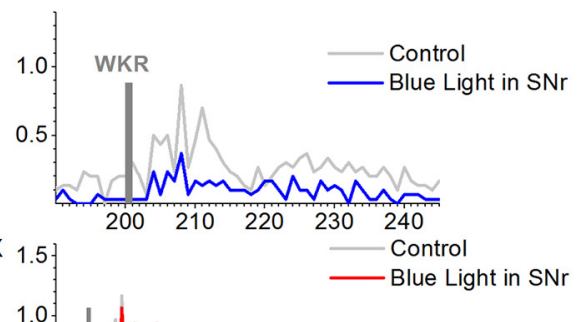

BCx

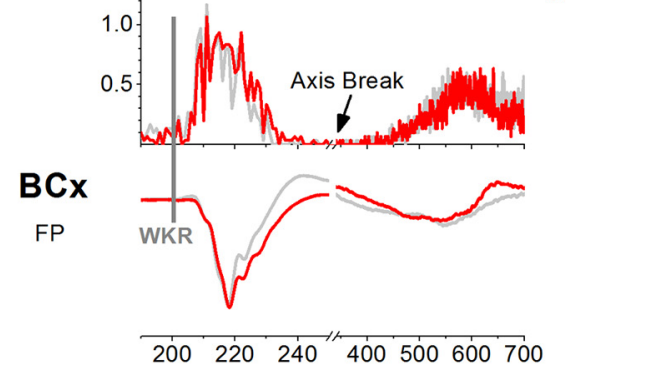

B
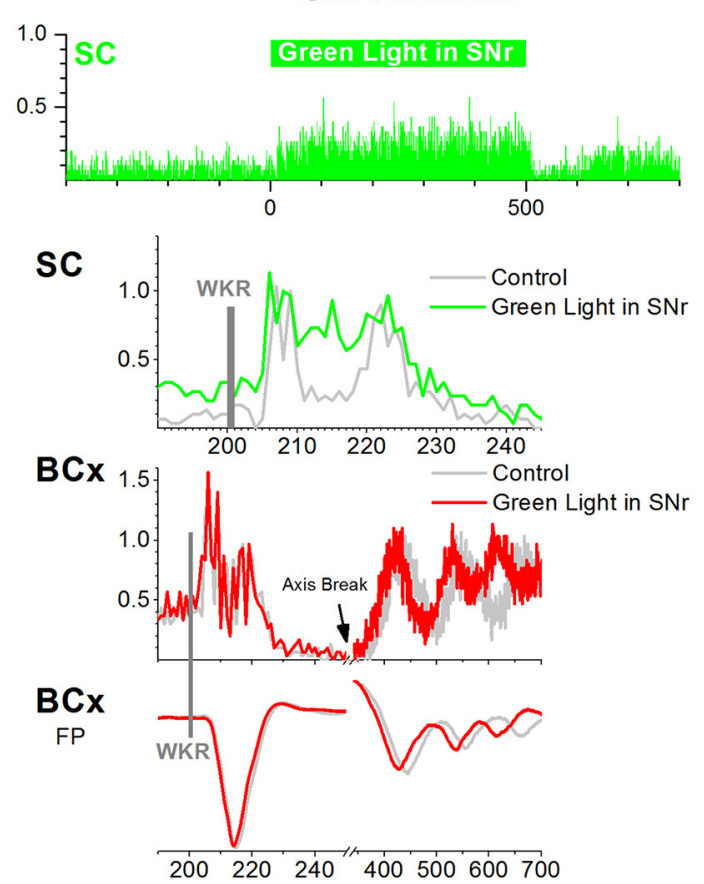

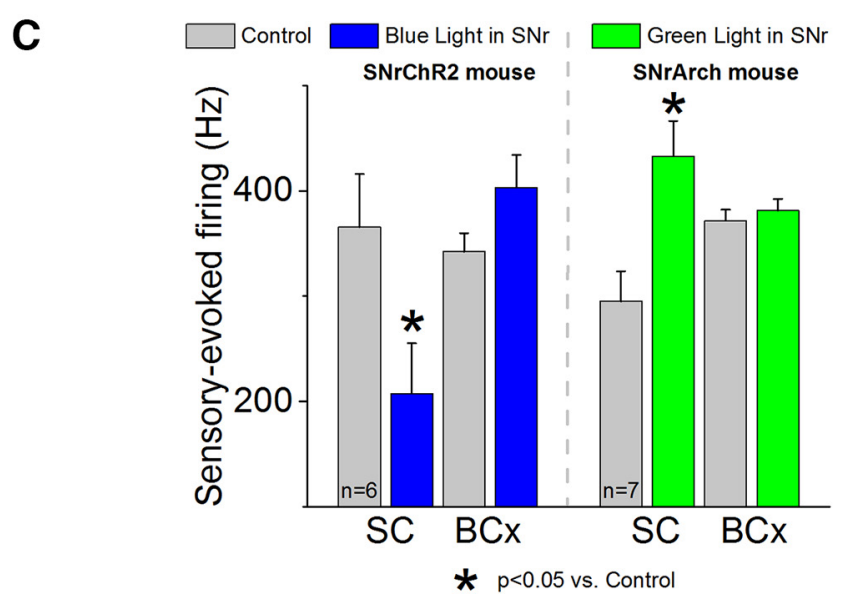

Figure 5. Effect of blue light in the SNr of a SNrChR2 mouse $(\boldsymbol{A})$ and green light in the SNr of a SNrArch mouse $(\boldsymbol{B})$ on sensory-evoked multiunit responses recorded simultaneously in the superior colliculus (SC) and barrel cortex (BCX). Panels overlay whisker-evoked (WKR) responses in the absence (control) or presence of light in SNr. Field potential (FP) responses recorded in barrel cortex are also shown. Each panel is the mean of 30 trials. The light is on for $500 \mathrm{~ms}$ and whisker stimulation is presented $200 \mathrm{~ms}$ after light onset. Barrel cortex traces are broken to show the whisker-evoked cortical rebound. C, Population data showing the effect of light in the SNr on whisker-evoked responses in the superior colliculus and barrel cortex. Responses are measured during a 50 ms window after the whisker stimulus.

percentage of avoidances $(n=16$ sessions in 3 mice; Tukey's test, $p=0.94$ ) and the latency from ACS onset (Tukey's test, $p=0.1$ ) did not differ significantly between LCS-alone and ACS trials within the same sessions. Moreover, spontaneous intertrial crossings were not affected. Together, the results from SNrChR2 and RosaArch mice show that increasing $\mathrm{SNr}$ firing abolishes active avoidance, whereas inhibiting $\mathrm{SNr}$ firing drives active avoidance.

During active avoidance, a black aluminum cap completely covered the head implant where the dual optic cannula and the optic fibers connected, blocking any exiting light. To ensure that animals were not able to use the light per se as a CS to drive avoidances, we implanted Vgat-Cre mice that did not express opsins with a bilateral cannula in the $\mathrm{SNr}$ or the overlying medial geniculate thalamus $(n=4)$. For several daily sessions, we pre- sented ACS-alone trials and LCS-alone trials (continuous) at the maximum green light intensity or at a blue light intensity four times higher than the maximum used during active avoidance. In all cases, the animals only avoided during presentation of the ACS (first three sessions of eight: avoidances mean \pm SEM, $16.6 \pm 3 \%$ LCS only, $93.3 \pm 3 \%$ ACS; Fig. $3 A$, NoOpsin) and performance to the ACS deteriorated over time (last three sessions of eight: avoidances mean \pm SEM, $13.3 \pm 3 \%$ LCS only, $24.4 \pm 8 \%$ ACS), consistent with the effects of presenting an unavoidable US. Therefore, animals were completely incapable of using the delivered light as a CS in the absence of opsin activation.

To test possible motor effects of our stimulation regimens after the last active avoidance session, we tested (Fig. 4) the effects of 2 s trains $(40 \mathrm{~Hz})$ of blue light pulses ( $1 \mathrm{~ms}$ ) applied unilaterally on movement bias in an open field (i.e., the tendency of an animal 
to move in a certain direction during active exploration). We tested $40 \mathrm{~Hz}$ trains because this frequency virtually completely blocks active avoidance. The head movement angle was tracked (100 frames per second video; $2 \mathrm{D} ; n=3$ mice) as mice spontaneously explored an open field. We found that, similar to the effect of activating the indirect striatonigral pathway, which excites SNr cells (Kravitz et al., 2010; Kravitz and Kreitzer, 2012; Freeze et al., 2013), trains of pulses $(40 \mathrm{~Hz})$ of blue light applied unilaterally in the $\mathrm{SNr}$ of $\mathrm{SNrChR} 2$ mice produced an ipsiversive turning bias as animals freely explored an open field. However, to produce a consistent ipsiversive movement bias with a $40 \mathrm{~Hz}$ train required using a blue light intensity that was about 10 -fold higher than the intensity used during active avoidance. In other words, at $40 \mathrm{~Hz}$, a consistent movement bias was only observed at the higher light intensities and not at the lower intensity used during active avoidance. These results indicate that the blue light stimulation intensities that we used to block active avoidance are at the lower end of the range for modulating $\mathrm{SNr}$.

\section{Effect of SNr firing on target structures}

The previous results demonstrate that exciting the $\mathrm{SNr}$ blocks active avoidance, whereas inhibiting $\mathrm{SNr}$ drives active avoidance. A main target of the $\mathrm{SNr}$ that is known to be involved in active avoidance is the superior colliculus (Cohen and Castro-Alamancos, 2007, 2010b). Therefore, we tested the effect of manipulating SNr firing on the spontaneous and sensory-evoked activity of cells in the intermediate layers of the superior colliculus in vivo. Sensory stimulation consisted of multiwhisker deflections (approximately six contralateral whiskers deflected simultaneously). In addition, to determine the selectivity of the effects observed in superior colliculus, we simultaneously measured whisker-evoked responses in the somatosensory (barrel) cortex. Note that we have also used whisker stimulation as a CS and that auditory and somatosensory afferents reach the same layers in superior colliculus.

We found that increasing the firing of $\mathrm{SNr}$ cells with continuous pulses of blue light ( $500 \mathrm{~ms}$ ) applied in the SNr of SNrChR2 mice significantly inhibited the firing of cells in the intermediate layers of the superior colliculus (paired ttest; $p<0.01 ; n=6$ sites in 2 mice; Fig. $5 A$, top). In addition, sensory responses evoked during $\mathrm{SNr}$ excitation (50 ms window, $200 \mathrm{~ms}$ after blue light onset) were significantly inhibited in the superior colliculus $(p<$ 0.01 ), but not in the barrel cortex, which actually tended to increase (Fig. $5 A$, bottom). These effects remained statistically significant when evoked responses were corrected by subtracting spontaneous firing. These results show that $\mathrm{SNr}$ excitation, which blocks active avoidance, inhibited spontaneous and sensoryevoked activity in the superior colliculus, whereas sensory responses reaching the neocortex were not suppressed.

Conversely, inhibiting the firing of $\mathrm{SNr}$ cells with continuous pulses of green light ( $500 \mathrm{~ms}$ ) applied in the SNr of SNrArch mice significantly increased the firing of cells in the intermediate layers of the superior colliculus (paired $t$ test; $p<0.01 ; n=7$ sites in 2 mice; Fig. $5 B$, top). Sensory responses evoked during SNr inhibition were significantly increased in the superior colliculus, but not in the barrel cortex (Fig. 5B, bottom). These effects remained statistically significant when evoked responses were corrected by subtracting spontaneous firing. Figure $5 C$ shows population data on the effects of exciting or inhibiting $\mathrm{SNr}$ cells on whiskerevoked responses in the superior colliculus and barrel cortex. The results emphasize that the effects of manipulating $\mathrm{SNr}$ are mostly restricted to its direct target, the superior colliculus; $\mathrm{SNr}$ does not produce a generalized action on sensory responses in other structures such as the barrel cortex.

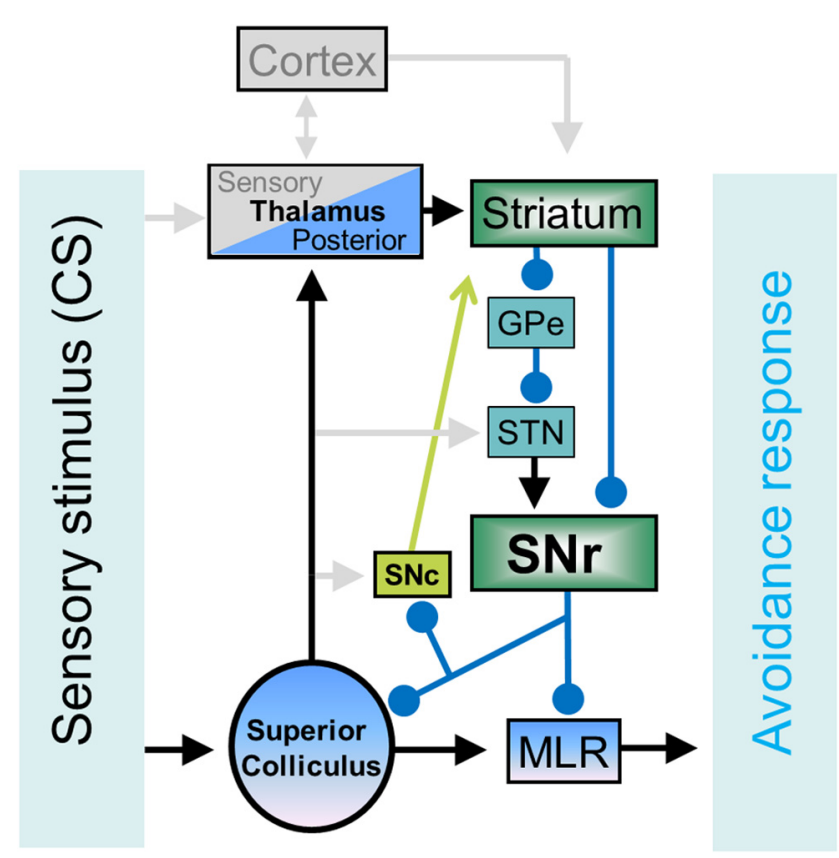

\section{Active avoidance performance circuit}

Figure 6. Schematic of the neural circuitry mediating active avoidance to a CS in well trained animals. The $C S$ ascends to the striatum via the superior colliculus projections to the posterior intralaminar thalamus. Basal ganglia processing leads to the suppression of $\mathrm{SNr}$, which drives avoidances by disinhibiting its targets in SNc, superior colliculus, and the midbrain circuitry that drives locomotion (mesencephalic locomotor region, MLR). Here, we showed that modulating $\mathrm{SNr}$ firing at the center of the circuit fully controls active avoidance behavior. GPe, Globus pallidus external; STN, subthahalamic nucleus.

\section{Discussion}

The results demonstrate that the output of the basal ganglia via $\mathrm{SNr}$ gates active avoidance. One interpretation of these results is that exciting SNr blocks movement, which impedes avoidance. Certainly, higher levels of SNr excitation can cause motor effects such as an ipsiversive bias (Fig. 4) that are similar to excitation of the indirect striatal pathway (Kravitz et al., 2010). However, with our stimulation levels, movement biases were minimal and animals moved about the cage during $\mathrm{SNr}$ excitation but did not avoid ACS + LCS trials (Movie 1). Moreover, they had no difficulty escaping the US, which requires the same movements as avoiding; the US may drive escaping via a more reflexive and higher-threshold brainstem route not involving SNr. If the animals had an impaired ability to move to avoid during $\mathrm{SNr}$ excitation, then they would also be incapable of escaping because avoids and escapes involve the same locomotor behavior.

An alternative interpretation is that exciting the $\mathrm{SNr}$ interferes with the ability of the CS to drive avoidance because the CS must inhibit the SNr to gate avoidance. This is supported by the finding that inhibiting SNr can drive avoidance in the absence of the CS. In other words, if $\mathrm{SNr}$ excitation were simply blocking movement, then $\mathrm{SNr}$ inhibition would not drive avoidance per se. It might drive disorganized movement, but not the directed movement needed to avoid. The CS-driven impaired avoidance caused by $\mathrm{SNr}$ excitation resembles the impaired avoidance (learned helplessness) that develops after subjects are exposed to situations in which the US is inescapable (Seligman 1972). SNr hyperactivity may be associated with the helplessness symptoms of depressive disorders and relieving it may have therapeutic benefits.

The CS may influence the basal ganglia via direct inputs from the thalamus and neocortex to the striatum. However, lesions of 
the sensory thalamus that block Pavlovian fear conditioning have little impact on active avoidance performance; these animals engage the superior colliculus for avoidance (Cohen and CastroAlamancos, 2007, 2010a). The superior colliculus forms loops with the basal ganglia (Comoli et al., 2003; Jiang et al., 2003; Dommett et al., 2005; McHaffie et al., 2005; Redgrave and Gurney, 2006; Coizet et al., 2009; Schulz et al., 2009); has an established role in detecting sensory stimuli that require immediate action, such as during visual orienting (Wurtz and Albano, 1980; Sparks and Mays, 1990; Stein and Meredith, 1993; Felsen and Mainen, 2008; Gandhi and Katnani, 2011; Krauzlis et al., 2013) or defensive reactions (Dean et al., 1989); and is involved in active avoidance (Cohen and Castro-Alamancos, 2007, 2010a, 2010b). Moreover, we show that $\mathrm{SNr}$ excitation that blocks avoidance does not suppress sensory responses ascending via the sensory thalamus to the neocortex, suggesting that an intact sensory thalamocortical pathway is not sufficient to sustain avoidance. Therefore, a more parsimonious avoidance circuit that obviates the need for the sensory thalamus may operate in well trained animals (Fig. 6). In this scenario, the CS ascends into the striatum via the posterior intralaminar thalamus driven by afferents from the superior colliculus (Linke, 1999; Krout et al., 2001). The neural activity driven in striatum by the CS would in turn suppress $\mathrm{SNr}$ firing and gate avoidance responses through inhibitory projections to deep layers of superior colliculus, PPT, and the cuneiform nucleus (Mitchell et al., 1988; Redgrave et al., 1988; Dean et al., 1989; Westby et al., 1990; Redgrave et al., 1993; Brandão et al., 1994), generally called the mesencephalic locomotor region (Skinner and Garcia-Rill, 1984; Jordan et al., 2008), which is known to project to locomotor central pattern generators in the medulla (Grillner, 2006). Future work will be needed to determine which of the targets of $\mathrm{SNr}$ is responsible for controlling avoidance. Solely inhibiting the superior colliculus without affecting thalamocortical processing (as we show here during $\mathrm{SNr}$ excitation) should not block active avoidance because the sensory thalamus and superior colliculus serve as alternative routes for active avoidance (Cohen and Castro-Alamancos, 2007). Therefore, SNr projections to PPT may be responsible for the control of avoidance reported here and this will be tested in future work. It is also important to note that our results do not imply that the $\mathrm{SNr}$ is dedicated solely to controlling active avoidance. In fact, we presume that the $\mathrm{SNr}$ similarly controls other CS-guided behaviors. Although the pathophysiology of basal ganglia disorders such as Parkinson's disease is complex (Albin et al., 1989), our results imply that deficits in sensory (cue)-driven locomotion in these disorders may be associated with abnormally augmented SNr output.

Understanding the circuitry involved in well established avoidance responses should be helpful to devise effective therapeutic approaches to alleviate engrained maladaptive avoidance responses that are pervasive during anxiety and depressive disorders in humans (e.g., avoiding social events in social phobia, avoiding places or thoughts in PTSD, avoiding exposure in obsessive-compulsive disorders).

\section{References}

Albin RL, Young AB, Penney JB (1989) The functional anatomy of basal ganglia disorders. Trends Neurosci 12:366-375. CrossRef Medline

Amorapanth P, LeDoux JE, Nader K (2000) Different lateral amygdala outputs mediate reactions and actions elicited by a fear-arousing stimulus. Nat Neurosci 3:74-79. CrossRef Medline

Barnes TD, Kubota Y, Hu D, Jin DZ, Graybiel AM (2005) Activity of striatal neurons reflects dynamic encoding and recoding of procedural memories. Nature 437:1158-1161. CrossRef Medline
Berridge KC (2007) The debate over dopamine's role in reward: the case for incentive salience. Psychopharmacology (Berl) 191:391-431. CrossRef Medline

Bolles RC (1970) Species-specific defense reactions and avoidance learning. Psychol Rev 77:32-48. CrossRef

Bolles RC, Grossen NE (1970) Function of the CS in shuttle-box avoidance learning by rats. J Comp Physiol Psychol 70:165-169. CrossRef Medline

Bouton ME (2007) Learning and behavior. Sunderland: Sinauer Associates.

Boyden ES, Zhang F, Bamberg E, Nagel G, Deisseroth K (2005) Millisecondtimescale, genetically targeted optical control of neural activity. Nat Neurosci 8:1263-1268. CrossRef Medline

Brandão ML, Cardoso SH, Melo LL, Motta V, Coimbra NC (1994) Neural substrate of defensive behavior in the midbrain tectum. Neurosci Biobehav Rev 18:339-346. CrossRef Medline

Castro-Alamancos MA (2004a) Absence of rapid sensory adaptation in neocortex during information processing states. Neuron 41:455-464. CrossRef Medline

Castro-Alamancos MA (2004b) Dynamics of sensory thalamocortical synaptic networks during information processing states. Prog Neurobiol 74: 213-247. CrossRef Medline

Chevalier G, Deniau JM (1990) Disinhibition as a basic process in the expression of striatal functions. Trends Neurosci 13:277-280. CrossRef Medline

Ciocchi S, Herry C, Grenier F, Wolff SB, Letzkus JJ, Vlachos I, Ehrlich I, Sprengel R, Deisseroth K, Stadler MB, Müller C, Lüthi A (2010) Encoding of conditioned fear in central amygdala inhibitory circuits. Nature 468:277-282. CrossRef Medline

Cohen JD, Castro-Alamancos MA (2007) Early sensory pathways for detection of fearful conditioned stimuli: tectal and thalamic relays. J Neurosci 27:7762-7776. CrossRef Medline

Cohen JD, Castro-Alamancos MA (2010a) Detection of low salience whisker stimuli requires synergy of tectal and thalamic sensory relays. J Neurosci 30:2245-2256. CrossRef Medline

Cohen JD, Castro-Alamancos MA (2010b) Neural correlates of active avoidance behavior in superior colliculus. J Neurosci 30:8502-8511. CrossRef Medline

Cohen JD, Hirata A, Castro-Alamancos MA (2008) Vibrissa sensation in superior colliculus: wide-field sensitivity and state-dependent cortical feedback. J Neurosci 28:11205-11220. CrossRef Medline

Cohen JY, Haesler S, Vong L, Lowell BB, Uchida N (2012) Neuron-typespecific signals for reward and punishment in the ventral tegmental area. Nature 482:85-88. CrossRef Medline

Coizet V, Graham JH, Moss J, Bolam JP, Savasta M, McHaffie JG, Redgrave P, Overton PG (2009) Short-latency visual input to the subthalamic nucleus is provided by the midbrain superior colliculus. J Neurosci 29: 5701-5709. CrossRef Medline

Comoli E, Coizet V, Boyes J, Bolam JP, Canteras NS, Quirk RH, Overton PG, Redgrave P (2003) A direct projection from superior colliculus to substantia nigra for detecting salient visual events. Nat Neurosci 6:974-980. CrossRef Medline

Cui G, Jun SB, Jin X, Pham MD, Vogel SS, Lovinger DM, Costa RM (2013) Concurrent activation of striatal direct and indirect pathways during action initiation. Nature 494:238-242. CrossRef Medline

Darvas M, Fadok JP, Palmiter RD (2011) Requirement of dopamine signaling in the amygdala and striatum for learning and maintenance of a conditioned avoidance response. Learn Mem 18:136-143. CrossRef Medline

Davis M, Whalen PJ (2001) The amygdala: vigilance and emotion. Mol Psychiatry 6:13-34. CrossRef Medline

Dean P, Redgrave P, Westby GW (1989) Event or emergency? Two response systems in the mammalian superior colliculus. Trends Neurosci 12:137147. CrossRef Medline

Delgado MR, Jou RL, Ledoux JE, Phelps EA (2009) Avoiding negative outcomes: tracking the mechanisms of avoidance learning in humans during fear conditioning. Front Behav Neurosci 3:33. CrossRef Medline

Di Chiara G, Porceddu ML, Morelli M, Mulas ML, Gessa GL (1979) Evidence for a GABAergic projection from the substantia nigra to the ventromedial thalamus and to the superior colliculus of the rat. Brain Res 176:273-284. CrossRef Medline

Dommett E, Coizet V, Blaha CD, Martindale J, Lefebvre V, Walton N, Mayhew JE, Overton PG, Redgrave P (2005) How visual stimuli activate 
dopaminergic neurons at short latency. Science 307:1476-1479. CrossRef Medline

Felsen G, Mainen ZF (2008) Neural substrates of sensory-guided locomotor decisions in the rat superior colliculus. Neuron 60:137-148. CrossRef Medline

Freeze BS, Kravitz AV, Hammack N, Berke JD, Kreitzer AC (2013) Control of basal ganglia output by direct and indirect pathway projection neurons. J Neurosci 33:18531-18539. CrossRef Medline

Gandhi NJ, Katnani HA (2011) Motor functions of the superior colliculus. Annu Rev Neurosci 34:205-231. CrossRef Medline

Graybiel AM (2008) Habits, rituals, and the evaluative brain. Annu Rev Neurosci 31:359-387. CrossRef Medline

Grillner S (2006) Biological pattern generation: the cellular and computational logic of networks in motion. Neuron 52:751-766. CrossRef Medline

Gulcebi MI, Ketenci S, Linke R, Hacıoğlu H, Yanalı H, Veliskova J, Moshé SL, Onat F, Çavdar S (2012) Topographical connections of the substantia nigra pars reticulata to higher-order thalamic nuclei in the rat. Brain Res Bull 87:312-318. CrossRef Medline

Gurney K, Prescott TJ, Redgrave P (2001) A computational model of action selection in the basal ganglia. I. A new functional anatomy. Biol Cybern 84:401-410. CrossRef Medline

Guyenet PG, Aghajanian GK (1978) Antidromic identification of dopaminergic and other output neurons of the rat substantia nigra. Brain Res 150:69-84. CrossRef Medline

Han X, Chow BY, Zhou H, Klapoetke NC, Chuong A, Rajimehr R, Yang A, Baratta MV, Winkle J, Desimone R, Boyden ES (2011) A high-light sensitivity optical neural silencer: development and application to optogenetic control of non-human primate cortex. Front Syst Neurosci 5:18. CrossRef Medline

Haubensak W, Kunwar PS, Cai H, Ciocchi S, Wall NR, Ponnusamy R, Biag J, Dong HW, Deisseroth K, Callaway EM, Fanselow MS, Lüthi A, Anderson DJ (2010) Genetic dissection of an amygdala microcircuit that gates conditioned fear. Nature 468:270-276. CrossRef Medline

Hikida T, Kimura K, Wada N, Funabiki K, Nakanishi S (2010) Distinct roles of synaptic transmission in direct and indirect striatal pathways to reward and aversive behavior. Neuron 66:896-907. CrossRef Medline

Hikosaka O, Wurtz RH (1983) Visual and oculomotor functions of monkey substantia nigra pars reticulata. I. Relation of visual and auditory responses to saccades. J Neurophysiol 49:1230-1253. Medline

Jiang H, Stein BE, McHaffie JG (2003) Opposing basal ganglia processes shape midbrain visuomotor activity bilaterally. Nature 423:982-986. CrossRef Medline

Jordan LM, Liu J, Hedlund PB, Akay T, Pearson KG (2008) Descending command systems for the initiation of locomotion in mammals. Brain Res Rev 57:183-191. CrossRef Medline

Kamin LJ, Brimer CJ, Black AH (1963) Conditioned suppression as a monitor of fear of the CS in the course of avoidance training. J Comp Physiol Psychol 56:497-501. CrossRef Medline

Killcross S, Robbins TW, Everitt BJ (1997) Different types of fearconditioned behaviour mediated by separate nuclei within amygdala. Nature 388:377-380. CrossRef Medline

Krauzlis RJ, Lovejoy LP, Zénon A (2013) Superior colliculus and visual spatial attention. Annu Rev Neurosci 36:165-182. CrossRef Medline

Kravitz AV, Kreitzer AC (2012) Striatal mechanisms underlying movement, reinforcement, and punishment. Physiology (Bethesda) 27:167-177. CrossRef Medline

Kravitz AV, Freeze BS, Parker PR, Kay K, Thwin MT, Deisseroth K, Kreitzer AC (2010) Regulation of parkinsonian motor behaviours by optogenetic control of basal ganglia circuitry. Nature 466:622-626. CrossRef Medline

Krout KE, Loewy AD, Westby GW, Redgrave P (2001) Superior colliculus projections to midline and intralaminar thalamic nuclei of the rat. J Comp Neurol 431:198-216. CrossRef Medline

Krypotos AM, Effting M, Kindt M, Beckers T (2015) Avoidance learning: a review of theoretical models and recent developments. Front Behav Neurosci 9:189. CrossRef Medline

LeDoux JE (2000) Emotion circuits in the brain. Annu Rev Neurosci 23: 155-184. CrossRef Medline

LeDoux JE, Gorman JM (2001) A call to action: overcoming anxiety through active coping. Am J Psychiatry 158:1953-1955. CrossRef Medline
Linke R (1999) Differential projection patterns of superior and inferior collicular neurons onto posterior paralaminar nuclei of the thalamus surrounding the medial geniculate body in the rat. Eur J Neurosci 11: 187-203. CrossRef Medline

Maren S (2001) Neurobiology of Pavlovian fear conditioning. Annu Rev Neurosci 24:897-931. CrossRef Medline

McHaffie JG, Stanford TR, Stein BE, Coizet V, Redgrave P (2005) Subcortical loops through the basal ganglia. Trends Neurosci 28:401-407. CrossRef Medline

Mineka S (1979) The role of fear in theories of avoidance learning, flooding, and extinction. Psychol Bull 86:985-1010. CrossRef

Mink JW (1996) The basal ganglia: focused selection and inhibition of competing motor programs. Prog Neurobiol 50:381-425. CrossRef Medline

Mitchell IJ, Dean P, Redgrave P (1988) The projection from superior colliculus to cuneiform area in the rat. II. Defence-like responses to stimulation with glutamate in cuneiform nucleus and surrounding structures. Exp Brain Res 72:626-639. Medline

Mowrer OH (1960) Learning theory and behavior. New York: Wiley.

Oleson EB, Gentry RN, Chioma VC, Cheer JF (2012) Subsecond dopamine release in the nucleus accumbens predicts conditioned punishment and its successful avoidance. J Neurosci 32:14804-14808. CrossRef Medline

Pape HC, Pare D (2010) Plastic synaptic networks of the amygdala for the acquisition, expression, and extinction of conditioned fear. Physiol Rev 90:419-463. CrossRef Medline

Poremba A, Gabriel M (1999) Amygdala neurons mediate acquisition but not maintenance of instrumental avoidance behavior in rabbits. J Neurosci 19:9635-9641. Medline

Redgrave P, Gurney K (2006) The short-latency dopamine signal: a role in discovering novel actions? Nat Rev Neurosci 7:967-975. CrossRef Medline

Redgrave P, Dean P, Mitchell IJ, Odekunle A, Clark A (1988) The projection from superior colliculus to cuneiform area in the rat. I. Anatomical studies. Exp Brain Res 72:611-625. Medline

Redgrave P, Westby GW, Dean P (1993) Functional architecture of rodent superior colliculus: relevance of multiple output channels. Prog Brain Res 95:69-77. CrossRef Medline

Redgrave P, Prescott TJ, Gurney K (1999) The basal ganglia: a vertebrate solution to the selection problem? Neuroscience 89:1009-1023. CrossRef Medline

Rescorla RA, Solomon RL (1967) Two-process learning theory: Relationships between Pavlovian conditioning and instrumental learning. Psychol Rev 74:151-182. CrossRef Medline

Richards CD, Shiroyama T, Kitai ST (1997) Electrophysiological and immunocytochemical characterization of GABA and dopamine neurons in the substantia nigra of the rat. Neuroscience 80:545-557. CrossRef Medline

Roozendaal B, Koolhaas JM, Bohus B (1993) The central amygdala is involved in conditioning but not in retention of active and passive shock avoidance in male rats. Behav Neural Biol 59:143-149. CrossRef Medline

Schmidt R, Leventhal DK, Mallet N, Chen F, Berke JD (2013) Canceling actions involves a race between basal ganglia pathways. Nat Neurosci 16:1118-1124. CrossRef Medline

Schultz W (1998) Predictive reward signal of dopamine neurons. J Neurophysiol 80:1-27. Medline

Schulz JM, Redgrave P, Mehring C, Aertsen A, Clements KM, Wickens JR, Reynolds JN (2009) Short-latency activation of striatal spiny neurons via subcortical visual pathways. J Neurosci 29:6336-6347. CrossRef Medline

Seligman ME (1972) Learned helplessness. Annu Rev Med 23:407-412. CrossRef Medline

Skinner RD, Garcia-Rill E (1984) The mesencephalic locomotor region (MLR) in the rat. Brain Res 323:385-389. CrossRef Medline

Smith Y, Bevan MD, Shink E, Bolam JP (1998) Microcircuitry of the direct and indirect pathways of the basal ganglia. Neuroscience 86:353-387. CrossRef Medline

Sparks DL, Mays LE (1990) Signal transformations required for the generation of saccadic eye movements. Annu Rev Neurosci 13:309-336. CrossRef Medline

Stein BE, Meredith MA (1993) The merging of the senses. Cambridge, MA: MIT.

Tai LH, Lee AM, Benavidez N, Bonci A, Wilbrecht L (2012) Transient stim- 
ulation of distinct subpopulations of striatal neurons mimics changes in action value. Nat Neurosci 15:1281-1289. CrossRef Medline

Tecuapetla F, Matias S, Dugue GP, Mainen ZF, Costa RM (2014) Balanced activity in basal ganglia projection pathways is critical for contraversive movements. Nat Commun 5:4315. CrossRef Medline

Tepper JM, Martin LP, Anderson DR (1995) GABAA receptor-mediated inhibition of rat substantia nigra dopaminergic neurons by pars reticulata projection neurons. J Neurosci 15:3092-3103. Medline

Tye KM, Deisseroth K (2012) Optogenetic investigation of neural circuits underlying brain disease in animal models. Nat Rev Neurosci 13:251-266. CrossRef Medline

Urban DJ, Roth BL (2015) DREADDs (designer receptors exclusively activated by designer drugs): chemogenetic tools with therapeutic utility. Annu Rev Pharmacol Toxicol 55:399-417. CrossRef Medline

Vong L, Ye C, Yang Z, Choi B, Chua S Jr, Lowell BB (2011) Leptin action on
GABAergic neurons prevents obesity and reduces inhibitory tone to POMC neurons. Neuron 71:142-154. CrossRef Medline

Westby GW, Keay KA, Redgrave P, Dean P, Bannister M (1990) Output pathways from the rat superior colliculus mediating approach and avoidance have different sensory properties. Exp Brain Res 81:626-638. CrossRef Medline

Wurtz RH, Albano JE (1980) Visual-motor function of the primate superior colliculus. Annu Rev Neurosci 3:189-226. CrossRef Medline

Wurtz RH, Hikosaka O (1986) Role of the basal ganglia in the initiation of saccadic eye movements. Prog Brain Res 64:175-190. CrossRef Medline

Zweifel LS, Fadok JP, Argilli E, Garelick MG, Jones GL, Dickerson TM, Allen JM, Mizumori SJ, Bonci A, Palmiter RD (2011) Activation of dopamine neurons is critical for aversive conditioning and prevention of generalized anxiety. Nat Neurosci 14:620-626. CrossRef Medline 